\section{1. はじめに（背景）}

近年の高速延伸仮撚機における加撚装置としては大き く分けて 2 種類のタイプが存在する.

- Friction Twister

- Nip Twister

それぞれのTwisterには加工特性により得意分野，不 得意分野が存在するが，多品種にわたるLOTを1つの Twisterで加工するという要望は非常に大きい。今回開 発したQuattronip Twisterはこの2つのTwisterの加工範 囲をカバーすることが目的である。

\section{Nip Twister と Friction Twister の比較}

高速延伸仮撚機の2種のTwisterにおける加工品種の最適 範囲は，Nip Twisterでは太糸・特殊糸，Friction Twisterで は細糸・ハイカウント糸・Nylon糸であり，生産工場にお いても Twisterごとに加工LOTが区別されている（図1)。

Friction Twister は互いに非接触な複数の円形Discを 屈曲的に配置することで構成され，糸のDiscへの押付 圧力とDisc が回転する際の摩擦力で糸に撚りを加える. またNip Twisterは2本のツイスターベルトが相反する 方向に回転し，2本のベルト間に一定接圧下で直接糸を はさみ込むことにより糸に撚りを加える（図2）.

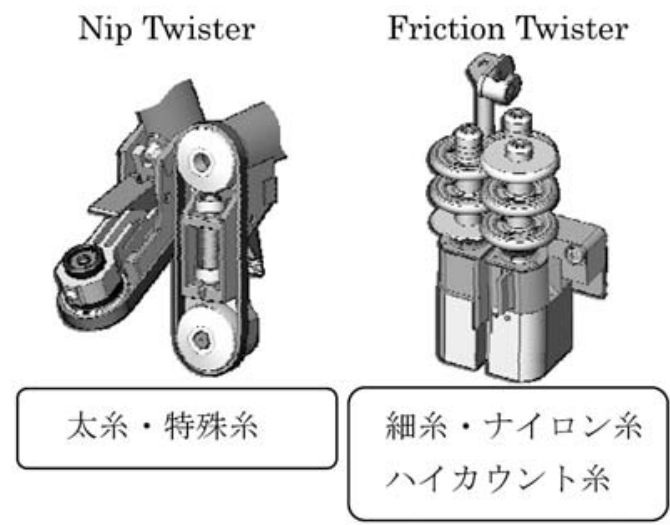

図 1 最適加工糸種
Friction Twisterは摩擦力のみで糸に撚りを加えるた め，太糸に対する加撚力には限界がある。逆にNip Twisterは糸を 2 本のベルトで直接挟みこむため，太糸 の把持性は強力であるが，細糸・ハイカウント糸の加工 においてはベルト同士の接触が発生し，加撚力の安定性 を損なう要因となる場合がある。このような構造上の差 がそれぞれのTwisterの最適加工糸種に影響していると 考えられる。

実際，生産工場において細糸・ハイカウント糸を生産 する場合，Nip Twisterの加工糸を Friction Twisterの加 工糸と比較すると糸品質上の弱点として下記の項目が挙 げられる。

(1)毛羽が比較的多い（特に Micro Filaments）

(2)細糸の加工性が悪い（断糸,生産速度）

これらの状況を改善し，且つ1つのTwisterで多品種 LOTの生産範囲をカバーするためにQuattronip Twister が製品化された.

\section{Quattronip Twister の構造}

Quattronip Twisterは下記の特長を有する.

(1) 4 本のベルトを使用する

(ニップ点数の増加，ニップ長増大）

(2)解撚部撚止ガイドを使用する.

(ハイカウント糸加工時)
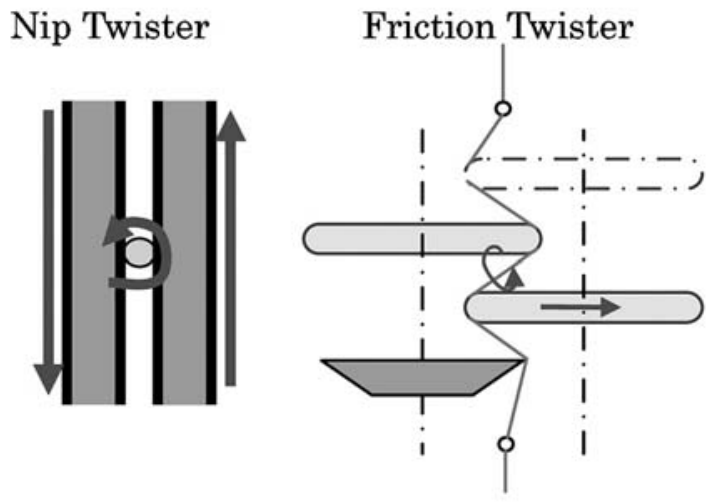

図 2 加撚形態 
Quattronip TwisterはNip Twister と比較してベルト接 触面積が増大したため, 低接圧での安定加工が可能とな った。 また糸把持長も増大され，低い圧力でもしっかり と糸を把持することができる(図 3 ).

この特長により細糸・ハイカウント糸の加工安定性を 大幅に改善することができ, 加工速度の上昇を実現した. またTwister 直後の解撚部の糸道を屈曲形状とし, Twister 直後の解撚部での糸の張力（T2'）を下げるこ とにより毛羽を抑制することができる.ささら屈曲ガイ ドに撚り止めガイドを使用することで低張力下でも確実 に解撚させることが可能となった（図4).

一方, 太糸の加工特性についても接圧を増加させるこ とにより従来型Nip Twister と同等に糸把持力が増大し, また糸把持長も増加しているため, Quattronipにおける 加工範囲は従来型Nip Twister 比較でもさらに広がった.

メンテナンス面においては, 撚数変更およびDISC交 換の際にはFriction Twisterでは3 軸を分解し, DISC交 換を実施する必要があったＱQuattronip Twisterにおい ては従来型 Nip Twister と同じく撚数変更についてはべ ルトの交差角度の変更のみで可能であり, ベルト交換に おいてはワンタッチ操作で交換が可能である.

\section{4. 試験結果および生産 DATA}

生産工場において実際にQuattronip を使用した場合

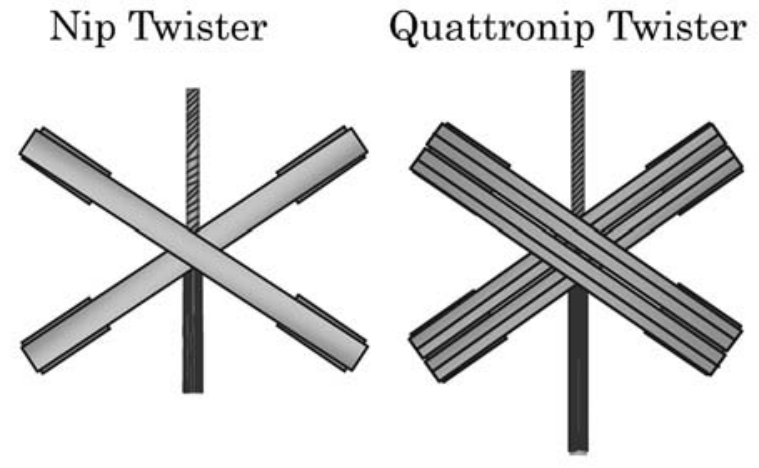

図3

Quattronip Twister構造
と, 従来型Nip Twister およびFriction Twisterを使用し た場合の加工品種ごとの断糸率，AM\%の比較結果を図 5 に示す（この $\mathrm{AM} \%$ とは最終検査終了後の一級品の完巻 率を示す).

Quattronip Twister使用時のデータは断糸率および AM\%の両方において, Friction Twisterおよび従来型 Nip Twister使用時のデータより良い結果が得られている.

特に83dT/144fの加工において, 従来型Nip Twister は毛羽や断糸等の問題が発生することがまれにあり， Friction Twisterでの生産が優先されていた. しかし Quattronip Twisterにおける結果ではFriction機よりも低 い断糸率と高いAM\%が実現され, 従来型Nip Twisterの 弱点が改善されたことがわかる.

次に $167 \mathrm{dT}$ 以上の太糸加工糸の糸物性に関して Quattronip Twister と従来型Nip TwisterおよびFriction Twisterを比較した試験結果を図 6 に示す.

167dT/48f，330dT/96f，660dT/192fの試験において Quattronip Twisterでの加工糸はFriction Twisterでの加 工糸と比較して伸度, 強度, 捲縮值ともに高い結果が得 られ物性的に良好であることがわかる（Friction Twister における660dT/192fの加工においてはDTYに未解撚が 混在し強度が極端に低い。これはFriction Twisterにお いては加撚力不足等の要因で660dTの糸加工が困難であ ることを示している).

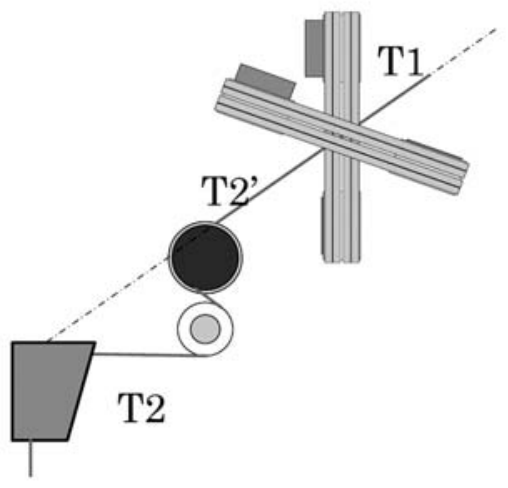

図4 解撚部の糸道

\begin{tabular}{|c|c|c|c|c|c|c|}
\hline & \multicolumn{3}{|c|}{ 断糸 (本/台・時間) } & \multicolumn{3}{c|}{ AM率 (\%) } \\
\hline Twister & Friction & 従来Nip & Quattronip & Frictoin & 従来Nip & Quattronip \\
\hline $\begin{array}{c}83 \mathrm{dT} / 72 \mathrm{f} \\
\text { 高捲縮 }\end{array}$ & 困難 & 1.21 & 0.54 & 困難 & 85.2 & 91.2 \\
\hline $83 \mathrm{dT} / 144 \mathrm{f}$ & 0.79 & 困難 & 0.40 & 92.6 & 困難 & 92.8 \\
\hline $167 \mathrm{dT} / 48 \mathrm{f}$ & 1.76 & 1.98 & 0.86 & 93.0 & 88.3 & 95.4 \\
\hline
\end{tabular}

図5 Quattronip生産機比較データ 

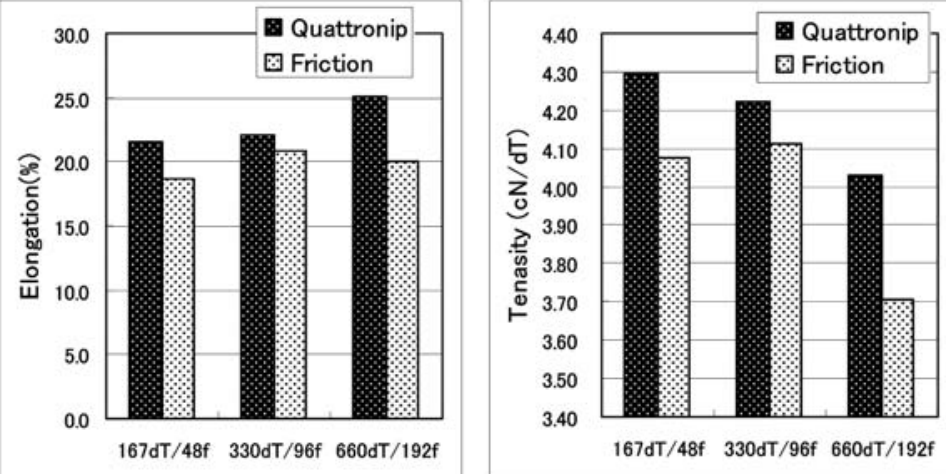

$167 \mathrm{dT} / 48 \mathrm{f} 330 \mathrm{dT} / 96 \mathrm{f} 660 \mathrm{dT} / 192 \mathrm{f}$

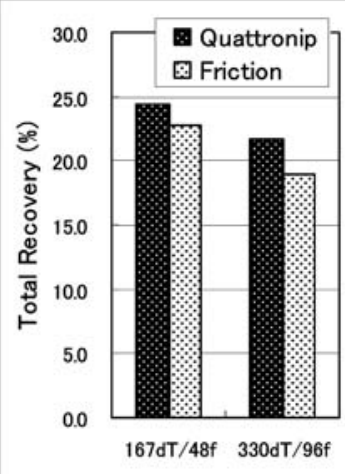

Total Recovery 測定 : Lowson-Hemphill 社 TYT 使用

167dT以上の加工試験データ

- Nip長の増大

- Nip 回数 増加

- 接圧面積の増大

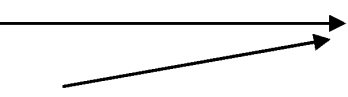

加撚力の増大と安定

- 解撚部の然り止めガイド

低実効接圧の安定

- 撚り数、張力の変更簡単

解撚点の安定, 毛羽抑制

多品種加工

図7 Quattronip 効果のまとめ

\section{5. まとめ}

Quattronip Twisterを使用することによる生産品質お よび生産効率向上等の利点が, 従来型Nip Twister およ びFrictionTwisterを使用する場合より大きいことはすで に説明したとおりであるが，QuattronipTwisterの特長
を再度まとめると図7のようになる。

現在，世界各国にQuattronip Twisterを装備した機種 が展開されつつあるが，当社の今後を担う主力機種とし て継続的に展開を支援する予定である.

一資料篇前付 4 頁参照一

出水良光 (でみずよしみつ)

1995 年, 同志社大学工学部機械系卒業, 同年, 村田機械(株)入社. 合繊機械の開発, 加工 糸プロセス開発，顧客サービスに従事. 2004 年, TMTマシナリー(株)へ転籍. 技術本部開 発部プロセスチームにて仮撚機の要素開発に従事.

片岡成典（かたおかしげのり） 1985 年, 大阪工業大学工学研究科機械工学部修士課程修了, 同年, 村田機械森入社. 合 繊機械の評価, 加工糸プロセスの研究に従事. 2004 年, TMT マシナリー(陎へへ転籍. 仮撚 機のプロセス, コンポーネント開発に従事. 現在, 技術本部開発部プロセスチームリーダ - .
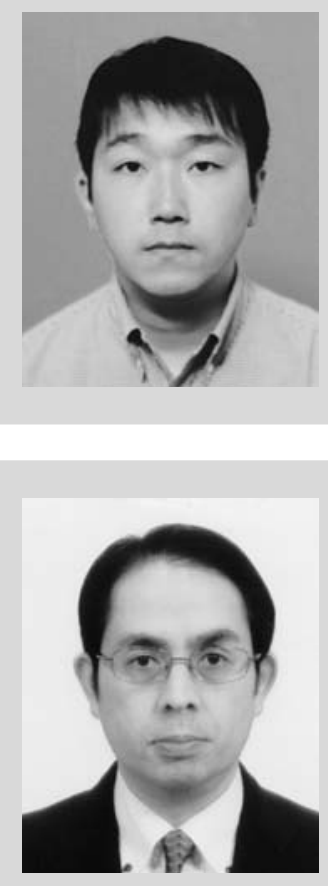